\title{
The emerging science of gastrophysics and its application to the algal cuisine
}

\author{
Ole G Mouritsen ${ }^{1,2}$
}

\begin{abstract}
This paper points to gastrophysics as an emerging scientific discipline that will employ a wide range of the most powerful theoretical, simulational and experimental biophysical techniques to study the empirical world of cooking and gastronomy. Gastrophysics aims to exploit recent advances in the physical sciences to forward the scientific study of food, its raw materials, the effects of processing food and quantitative aspects of the physical basis for food quality, flavour and absorption into the human body. It suggests the use in cooking of a class of raw materials little used in the Western world, the marine macroalgae or seaweeds, as a laboratory for defining, characterizing and shaping the emerging scientific discipline of gastrophysics. In relation to gastronomy, seaweed materials are virtually unexplored scientifically by physical experimentation and theory. The sea is one of the last resorts for humankind to exploit the ability to obtain more food to feed a hungry world, because world fisheries can no longer meet the need for healthy seafood. Hence, seaweeds offer a rich and virtually unexploited source of primary marine foodstuff in the Western world. To explore the full gastronomical potential of this resource, there is a need for fundamental research into the gastrophysics of seaweeds.
\end{abstract}

Keywords: gastrophysics, molecular biophysics, algae, seaweeds, science of cooking

\section{Gastronomy and gastrophysics}

The father of gastronomy, Jean Anthelme Brillat-Savarin, defined 'gastronomy' in his 1825 masterpiece, Physiologie du goût (The Physiology of Taste) [1], as the knowledge and understanding of everything that relates to man as he eats. Its purpose is to ensure the conservation of men, using the best food possible. Nowadays, 'gastronomy' is used as a broad term that covers the art and science of good cooking, including aesthetics, the qualities of raw materials, food preparation and cooking techniques, flavour and the cultural history of cooking. A wide range of established scientific disciplines relate to gastronomy, in particular food chemistry and technology, sensory sciences and human nutrition. A recent trend, pioneered by the British-Hungarian physicist Nicolas Kurti [2] and the French chemist Hervé This $[3,4]$ and fuelled by a close collaboration between scientists and chefs, has led to the new term 'molecular gastronomy'. A closer inspection of what molecular gastronomy is claimed to be shows that in most

Correspondence: ogm@memphys.sdu.dk

${ }^{1}$ MEMPHYS, Center for Biomembrane Physics, Department of Physics, Chemistry and Pharmacy, University of Southern Denmark, Campusvej 55, DK-5230 Odense M, Denmark

Full list of author information is available at the end of the article cases it tends to involve few if any quantitative molecular considerations. Despite the somewhat misleading terminology, or maybe exactly because of the use of this terminology, molecular gastronomy has received a lot of publicity among the general public and celebrated chefs. Some prominent chefs, including Heston Blumenthal, from restaurant The Fat Duck, and Ferran Adrià, from restaurant El Bulli, have issued disclaimers stating that their art and style of cooking cannot be described by the concept of molecular gastronomy [5].

In a recent review of molecular gastronomy, the British physicist Peter Barham and his colleagues [6] made a serious attempt to define what molecular gastronomy is and how it differs from gastronomy. These authors advocate the very pragmatic viewpoint that molecular gastronomy "should be considered as the scientific study of why some food tastes terrible, some is mediocre, some good, and occasionally some absolutely delicious" (p. 2315). In this way, they strike a delicate balance between, on the one hand, considering food simply as materials with certain properties described by food chemistry, and, on the other hand, taking into account the empirical fact that there are very passionate feelings associated with food and 
eating. Although according to this definition there seems to be no specific reference to why the term 'molecular' is invoked, it is presupposed that the field is based on the utilisation of molecularly based sciences such as chemistry for the scientific and systematic study of all aspects of food, including raw materials, cooking procedures, flavour, acceptance of food and systematisation of recipes and cooking procedures. In contrast, aspects of human nutrition and health are less emphasised. The Barham et al. review ultimately concludes that "perhaps the most important objective of [molecular gastronomy] should be to delineate the essential principles that underpin our individual enjoyment of food" [6] (p. 2361).

Molecular gastronomy heavily relies on well-established sciences such as food chemistry, general food science and food-processing technology, which are themselves, of course, of seminal importance for the food industry [7-9], although it has been claimed that there is very little science in the food industry [10]. A related focus on the chemistry of food is internalized in a less well-defined discipline called 'culinary chemistry', a term directly inspired by the title of an 1821 book by the German chemist Friedrich Accum, who wrote about the practical aspects of applying scientific principles, in particular chemistry, to cooking [11].

The application of physical principles to study foods from a materials science perspective is well-established in research on food physics and food biophysics [12], with a focus on physical and physicochemical properties such as texture, foam stability, emulsification properties, phase transformations, the physical principles underlying cooking processes and so on. These approaches are traditionally separated from sensory sciences, and they are often less concerned with gastronomical considerations. Several popular science books are embodiments of this category [13-18]. The most celebrated monograph on the science of cooking is Harold McGee's by now classic and encyclopaedic monograph, On Food and Cooking: The Science and Lore of the Kitchen [19].

In recent years, the collaboration between famous chefs and scientists has materialized in cookbooks that contain a significant element of scientific explanations, such as Heston Blumenthal's The Fat Duck Cookbook [20], and books that focus on the science of particular types of food, such as the science of ice cream [21], chocolate [22,23], pizza [24] and sushi [25]. The most recent development in writing on the science of cooking is embodied in the monumental five-volume tome by Nathan Myhrvold and colleagues on what is called 'Modernist Cuisine' [26]. To date, Myhrvold's books provide the most comprehensive accounts of the physical aspects of food and cooking and could well qualify as a gastrophysical body of work, although he and his colleagues do not use the term 'gastrophysics' in their five-volume series. In fact, very little, if anything, that can be called 'scientific' is written about gastrophysics $[27,28]$, and there appear to be no published scientific papers about gastrophysics.

It is the contention of the present paper that gastrophysics has as its goal the demonstration that fundamental principles of physics, in particular soft matter physics, biophysical chemistry and molecular biophysics, can and should be brought together in scientific work dealing with food and should focus on molecular aspects, as well as scientific mechanisms and explanations, and their relation to gastronomy to a much higher degree than traditional food chemistry and food physics. The perspective on the plethora of possible research activities within gastrophysics should be gastronomy itself. Gastrophysics takes gastronomy as its departure point of inspiration and uses gastronomical problems as a driving force. The intrinsic dynamics of this way of doing science is very similar to what has been witnessed in recent decades in the case of another emerging field of science, biological physics [29], which deals with biologically inspired physics problems. Biological physics not only solves problems in biology but also contributes to physics in general by revitalizing it and opening up a new empirical world for physicists. In a similar vein, gastrophysics uses gastronomical problems as a motor. Gastrophysics hence places itself as an emerging new scientific and molecularly based subdiscipline at the borders between soft matter physics and chemistry, culinary sciences, food chemistry and molecular gastronomy.

It is to be expected that a sufficiently original, ambitious and courageous research endeavour should be able to make significant advances in defining the emerging and little developed field of gastrophysics and demonstrate where it could lead. This is not to say that the various experimental, computational and theoretical methodologies, typical of the three pillars of modern natural science, which should be applied to gastrophysics, are in a similarly less advanced and less well-defined stage. On the contrary, the idea is to use, so to speak, the 'sharpest knives in the kitchen' to carve out the future of the field. These 'knives' include molecular simulation, single-molecule studies of taste, high-resolution microand nanoscale visualisation of macromolecular aggregates of food molecules and particles, measurements of physical forces controlling the stability of food formulations, molecular-structural characterization of raw food materials and their transformation during preparation, cooking, ageing, drying, conservation and fermentation, as well as the design of physical model systems tailored to mimic, for example, the absorption of food molecules and food particles in the intestines. All of these approaches are highly sophisticated and advanced and are likely to make a strong impact on the emerging field of gastrophysics.

The present paper suggests that a unique and clearcut opportunity exists to carve out the future for 
gastrophysical research by focusing attention on a specific class of materials, the marine macroalgae or seaweeds, which are virtually unexplored in a quantitative gastronomical setting. The bidirectional value of the approach, as implied by the analogy described above regarding biological physics, can then be assessed by investigating (1) how gastrophysics contributes to developing the algal cuisine and (2) how a focus on algae helps to frame gastrophysics as an emerging science.

\section{Use of gastrophysics to explore and gastronomically chart a new territory: the kingdom of algae}

The food we eat is derived from the mighty biological kingdoms of animals, plants and the fungi, as illustrated in Figure 1. Each kingdom contributes to our food and food cultures, with each their varieties in species, nutritional value and taste. Yet another big kingdom is out there which we hardly use for food: the algae. In terms of organic production on Earth, the algae are by far the most important, and because algae also perform photosynthesis, they are the main suppliers of atmospheric oxygen [30]. Algae are not plants, although the green algae are believed to be the ancestors of the higher (flowering) plants. Algae are at the bottom of the food chain, hence they are the primary source of many of the valued nutrients, as well as flavour compounds, that end up in, for example, marine animals such as fish and shellfish.

The algal kingdom is a very diverse group of organisms, many of which are only very distantly related [30,31]. The unicellular algae constitute the largest group. Some of them are related to plants, whereas others are bacteria, such as the green-blue algae, which are cyanobacteria. The multicellular algae that live in the sea are called 'marine macroalgae' or 'seaweeds'. Seaweeds are traditionally classified into three categories: brown, red and green seaweeds. The classification scheme is the subject of much dispute, and it is noteworthy that the brown and green seaweeds are, loosely speaking, genetically as distinct as plants and animals [32] (Figure 1). There are about 10,000 different species of seaweeds, and seaweeds are found in all climatic regions of the globe. It is interesting to note that whereas many plants and fungi are poisonous and unsuitable for human consumption, all seaweeds harvested in clean water are not poisonous, except for a few species in the tropics. Viewed in this light, seaweeds comprise a rich new territory for gastronomical exploitation and innovation which is almost

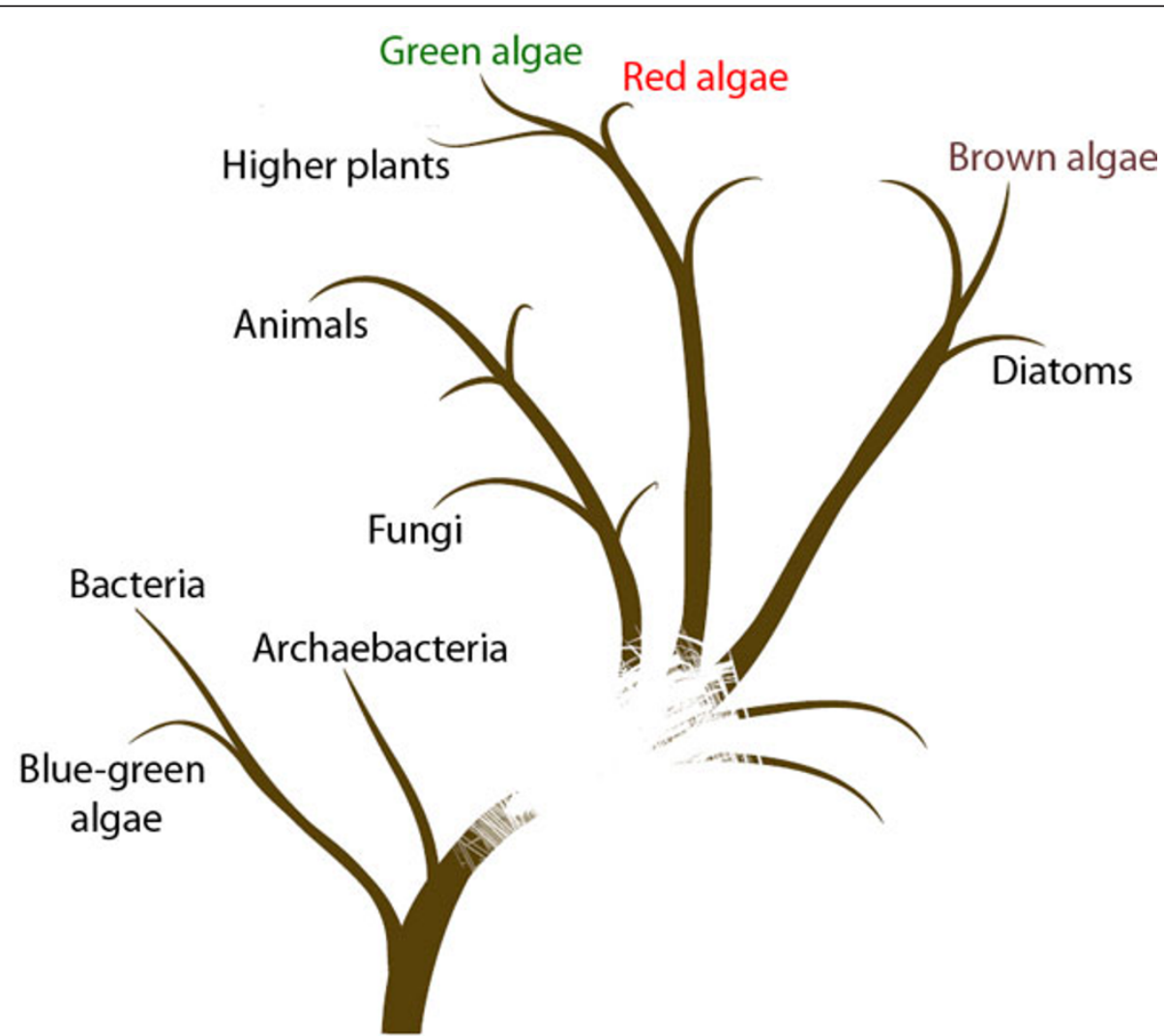

Figure 1 The tree of life. The phylogenetic tree highlighting the three classes of marine macroalgae: the green, the red and the brown seaweeds. 
comparable in richness to the addition of the plant kingdom to a hypothetical cuisine based only on animal products.

The marine macroalgae are an almost unexploited resource for primary foodstuff in the Western world, whereas it is an essential part of the daily diet in the East [33]. In the West, however, and in Europe in particular, seaweeds are exploited mostly as extracts for additives and stabilizers in processed food, specifically alginate, carrageenan and agar (E400-E407). There is, however, a growing interest in North America and some parts of Europe in using raw and processed forms of seaweeds as foods and food supplements, and one also notices that an increasing interest in healthy Asian food stimulates a local demand for seaweeds such as nori, wakame and konbu. In Europe and North America, small companies in Iceland, Brittany, Wales, Ireland, Maine, British Columbia and California produce and market various forms of dried and salted seaweed products for human consumption.

To put the potential of an algal cuisine into the context of sustainability, it should be remarked that the sea is one of the last resorts for humankind to exploit for obtaining more food to feed a hungry world. The domestication of species in the ocean is now increasing at a much more rapid speed than terrestrial species [34], and the ocean holds the greatest potential for obtaining more food. Furthermore, food from the ocean, that is fish, shellfish and marine algae, is known to be beneficial for human nutrition as well as for general health and well-being [35]. However, fisheries can no longer meet the needs of the world population [36].

Seaweeds are in many ways optimal for human nutrition because they contain a bounty of important minerals, trace elements, vitamins, proteins, iodine and polyunsaturated fatty acids, which are listed in Table 1 [35,37-46]. Moreover, seaweeds have plenty of soluble and insoluble dietary fibres ( $45 \%$ to $75 \%$ ) and hence contain few calories. Their actual composition depends very much on the seaweed species, age, location of growth, time of harvesting and storage conditions. The protein content varies generally from $7 \%$ to $35 \%$, and it involves most of the essential amino acids. Nori (Porphyra spp.) is one of the seaweeds with the highest amount of protein. The mineral content of seaweeds is generally ten times higher than that of terrestrial plants. It is noteworthy that the salty taste of many types of seaweed is due to a large extent to potassium salts, which generally outbalance the sodium salts. This makes seaweeds a good salt substitute in food and may be a way of combating the increasing global problem of hypertension.

Although the fat content of seaweeds is generally low (about $2 \%$ to $3 \%$ on a dry weight basis), it is noteworthy
Table 1 Important nutritional elements in seaweeds ${ }^{a}$

\begin{tabular}{|c|c|}
\hline Nutrients in seaweeds & Composition \\
\hline $\begin{array}{l}\text { Proteins, essential amino } \\
\text { acids }\end{array}$ & $7 \%$ to $35 \%$ \\
\hline $\begin{array}{l}\text { Dietary fibres (soluble, } \\
\text { insoluble) }\end{array}$ & $45 \%$ to $75 \%$ \\
\hline Vitamins & $A, B\left(B_{1}, B_{2}, B_{3}, B_{6}\right.$ and $B_{12}$ of folate), $C, E$ \\
\hline lodine & $\begin{array}{l}\text { Variable large amounts in some brown } \\
\text { species }\end{array}$ \\
\hline \multicolumn{2}{|c|}{ More $\mathrm{K}^{+}$salts than $\mathrm{Na}^{+}$salts } \\
\hline Minerals & $\mathrm{Fe}, \mathrm{Ca}, \mathrm{P}, \mathrm{Mg}, \mathrm{Cl}$ \\
\hline Trace compounds & $\mathrm{Zn}, \mathrm{Cu}, \mathrm{Mn}, \mathrm{Se}, \mathrm{Mb}, \mathrm{Cr}$ \\
\hline Essential fatty acids & $(2 \%$ to $5 \%), \omega-3$ (EPA, no DHA), $\omega-6$ (AA) \\
\hline
\end{tabular}

${ }^{a} \mathrm{AA}$, arachidonic acid; DHA, docosahexaenoic acid; EPA: eicosapentaenoic acid. The actual composition depends very much on the species, its age, the location of growth and the time of harvesting $[35,37-46]$. Percentages refer to dry weight.

that generally more than one-half of the fat is made up of unsaturated fatty acids, the majority of which are essential polyunsaturated $\omega-6$ and $\omega-3$ fatty acids [35]. An important group of $\omega-6$ and $\omega-3$ fatty acids are the very long and superunsaturated fatty acids, specifically arachidonic acid (AA) in the $\omega-6$ family and eicosapentaenoic acid (EPA) and docosahexaenoic acid (DHA) in the $\omega-3$ family. Whereas microalgae contain all three of these fatty acids, it is noteworthy that seaweeds contain only AA and EPA and very little, if any, DHA. An interesting observation is that the ratio of the amount of $\omega-3$ to $\omega-6$ fatty acids in seaweeds is in the range of unity or even greater in certain cases [35,41]. This should be contrasted to a typical European or North American diet, which has ratios of about 0.1 and 0.05 , respectively [47]. Nutritionists generally recommend that the diet be equally balanced with regard to $\omega-3$ and $\omega-6$ fatty acids [47]. The severe imbalance toward too much $\omega-6$ in the Western diet is believed to be one of the main causes of the burden of ill health, in particular in relation to heart and coronary diseases, obesity, diabetes and certain mental diseases [48-50]. Because seaweeds contain large amounts of natural antioxidants such as polyphenols [37], one can speculate that these antioxidants are instrumental in protecting the polyunsaturated fatty acids in the seaweeds when they are used as whole foods. Little is known to this effect, and a study of these important fatty acids, their amounts, their flavours and their bioavailability in foods could well turn out to be a rewarding gastrophysical project.

Seafood, including seaweeds, was probably the most important component of our ancestors' diet and part of the basis for the evolution of our brain and neural system, which are characterized by a large content of the superunsaturated $\omega-3$ and $\omega-6$ fatty acids at a proportion close to 1:1 [50]. Seaweeds may therefore be considered to be brain food, and it is their polyunsaturated 
fatty acid content and their perfect balance between $\omega-3$ and $\omega-6$ fatty acids that are particularly beneficial for our health.

Seaweeds can be harvested in the wild or grown in the sea in large amounts in a sustainable fashion. Undoubtedly, seaweeds will become a larger part of our daily diet in the future. Importantly, these "vegetables of the sea' will help us to renew and balance our diet and may contribute to combating the increased incidence of Western lifestyle-related diseases, in particular cardiovascular and heart diseases, such as hypertension, cancer and obesity, as well as mental disorders $[47,49]$.

A 2010 international seaweed symposium [51] rallied key actors in the science and use of seaweeds for foodstuff and also attracted practitioners in the fields of aquaculture, the food industry, gastronomy, nutrition and the health sciences. It became clear at the conference that there is a very strong and growing interest in seaweeds as food, and it was concluded that there is an urgent need for more research and the establishment of scientifically based knowledge about the uses of seaweeds for human consumption in people's ordinary diets, in futuristic functional foods and in gastronomy at all levels.

Therefore, to introduce the algal cuisine in the Western world, there is a need for a gastronomically inspired approach to using algae in cuisine. It is the contention of the present paper that the emerging science of gastrophysics can be defined and can show its potential by being applied to algal cuisine.

\section{Traditional uses of algae in cooking}

Whereas many microalgae, in particular spirulina [52] and Chlorella [53], are widely used for human consumption and food supplementation, in particular because of their high content of proteins, essential fatty acids and various minerals, these algae are not particularly interesting for gastronomical uses, except possibly for their unique ability to impart a green hue to dishes and drinks such as 'smoothies'. Microalgae generally have no interesting taste and texture. In contrast, macroalgae are very interesting, in particular because of their flavours and textures.

Although brown, red and green seaweed species have been eaten by all coastal peoples since prehistoric times [54], the regular consumption of seaweeds has predominantly survived to the present primarily in the contemporary cuisines of Asian countries such as Japan, Korea, China and the Philippines. In Japan especially, seaweeds are both fully integrated into the daily diet and used to create gastronomic specialties. Elsewhere seaweeds are now overwhelmingly linked to the preparation of Asianstyle meals. Nevertheless, the globalization of foods such as sushi has raised their profile in North America and, increasingly, in Europe.
The traditional use of seaweeds as part of the normal diet has almost died out in the Western world, but it can still be encountered here and there. The pattern of consumption is on an upward trend, however, no doubt driven by an awareness of its possible beneficial effects on overall health. In Europe, and particularly in Ireland [55], there are signs of a revival of interest in cooking with seaweeds, although this is still considered quirky and exotic. Many of today's leading chefs, however, have become fascinated with marine algae and are experimenting with their tastes, textures and colours in familiar dishes and in exciting, new gastronomic creations.

In some of the coastal areas of North America and northern Europe, the traditional consumption of seaweeds has been preserved and has become more prominent in the past few decades. This is especially the case in California and Maine in the United States, in British Columbia and Nova Scotia in Canada, and in Iceland, where dried seaweeds are now available in many supermarkets. In Europe, seaweeds still have a place in the popular cuisines of Brittany, Wales and Ireland. In Iceland, dulse is eaten in dried form as a snack and is mixed into salads, bread dough or curds, just as it was in the time of the sagas. Chefs in Scandinavia are actively finding creative ways to use seaweeds in fusion dishes as part of a revitalization of the Nordic food cultures of former times and the rise of the New Nordic Cuisine [56].

\section{Seaweeds in gastronomy}

Whereas there is a large body of scientific literature about the nutritional composition of various seaweeds, in particular with respect to protein, fibres, carbohydrates, minerals and fatty acids (see [35,37-46]), virtually no scientific studies of the basic physical and physicochemical properties of seaweeds in the context of gastronomy and gastronomical innovation have been undertaken. This is surprising, considering that the world market for seaweeds for human consumption amounts to almost $\$ 10$ billion annually. Over the past few years, the interest among the public and chefs up to the Michelin star level has been on a steep increase. At the same time, some European aquaculturists have expressed an interest in farming seaweeds for human consumption.

It is the seaweeds' content of high amounts of minerals, proteins and essential amino acids, trace elements, vitamins, iodine, low-calorie dietary fibres and polyunsaturated fatty acids which underlie their many nutritional qualities as human foodstuff. This is well-recognized in the East, such as in China, Korea and Polynesia, and particularly in Japan, where seaweeds are an essential part of the classic cuisine and highly regarded for their nutritional value, flavour and texture [33].

In the Western world, the interest in using seaweeds for cooking was stimulated by the macrobiotic diet 
movement in the 1960s and 1970s. Judith Cooper Madlener's classic seaweed cookbook was published during this period [57]. Later the globalization of Asian food, in particular sushi from Japan and its revival in Californian cuisine, introduced seaweeds such as konbu, wakame and particularly nori to the Western palate [25]. A number of cookbooks focused on seaweeds were subsequently published, many of them with reference to the macrobiotic and health food movements [58-66], others with a firm basis in the experience of individual seaweed harvesters [67-70] and a few books penned by scientists $[35,55,71]$.

Seaweed as a novel raw material for foods has a unique potential for gastronomical and sensory innovation. Although it has been used for centuries in other parts of the world, a serious and dedicated research program has to be carried out to develop and exploit this potential in a Western context and for the Western palate. It is noteworthy that whereas a very substantial body of scientific literature exists on seaweed farming, processing and nutrition, there is hardly any sciencebased sensory and gastronomical knowledge about seaweeds available on the international scene. Prominent exceptions are studies of the large brown seaweed konbu as a source of umami related to its contents of monosodium glutamate [56,72-75]. Together with 5'ribonucleotides such as inosinate and guanylate, glutamate promotes synergistic flavour enhancement effects (umami) [76] and may have applications in salt and sugar reduction in a variety of foods, including meats $[75,77,78]$.

Probably no other ingredients used for cooking are as versatile as seaweeds. They can be eaten raw, cooked, baked, toasted, puréed, dried, granulated or deep-fried. They can be eaten on their own or combined in countless ways with other cold or hot ingredients. In most instances, the seaweeds are believed to retain the greater part of their nutritional value in unchanged form, although much research along these lines is needed.

One can turn for inspiration to the greater attention that has been paid to marine algae during the past few years by many serious practitioners of 'haute cuisine'. This has been driven to a certain extent by a felicitous combination of factors: the locavore movement, a much greater consciousness of promoting sustainable food sources and the desirability of eating healthy, pesticidefree foods.

For the professional chef, the challenge of how to use raw materials is on a completely different plane from the one faced in the home kitchen. Like art and the search for new knowledge, gastronomy is driven by a combination of craft, desire for renewal, self-criticism, vision and delight in playing with new ingredients and ideas. For most chefs in Europe and North America, seaweeds are a relative novelty, which inspires them to rework traditional recipes in daring ways and to devise pioneering gastronomic experiences.

In inventive gastronomy, the goal is to invent fabulous new dishes in which seaweeds have been incorporated as essential, and often surprising, elements, which elevate the resulting creation to something unique and possibly sublime, something that calls out for both sensory and aesthetic appreciation. Well-known chefs have already embraced the use of seaweeds in their kitchens and restaurants to capitalise on the profusion of tastes, textures, shapes and colours that are characteristic of marine algae. Often this involves making excursions to harvest fresh seaweeds from their local surroundings, a natural extension of the quest for wild, edible plants and herbs in forests and fields. Others have drawn inspiration from classic Asian cuisine, where seaweeds have retained a prominent role.

One might wonder how the patrons of high-end expensive restaurants react to finding seaweeds on the menu. It seems that part of the appeal lies in the ingredients themselves. The diners appear to be intrigued by the idea of eating seaweeds and take an interest in learning more about them and their places of origin. In this way, tasty and flavourful marine algae may win a permanent place on the menu and, in the future, be featured more prominently, which would represent a vindication for the food of our ancestors.

\section{Research questions for gastrophysics applied to the algal cuisine}

The present paper has advocated the viewpoint that there is a need to apply concepts, methodologies and state-of-the-art methods from physics and biophysical chemistry to solve gastronomically inspired problems. This approach which we call 'gastrophysics' employs a wide range of the most powerful theoretical, simulational and experimental biophysical techniques to study the structure, dynamics and functional properties of raw and processed foodstuff with a focus on small-scale, macromolecular physical properties and how they relate to flavour and texture.

Among many others, the following could be some of the specific focal areas of the gastrophysical study of seaweeds: (1) visualization and characterization of structure on the small scale of raw and processed seaweeds; (2) determination of the stability and micromechanical properties of foodstuff derived from seaweeds and optimisation of these properties with respect to enhanced taste, mouthfeel and flavour; (3) measurement of the release of flavour compounds as well as the absorption and transport of algal food particles and nutrients via physical models of the intestinal barrier; (4) assessment of the biophysical properties of the precious $\omega-3$ fatty 
acids and sterols synthesised by algae and the effect of seaweed bioactive compounds on cell membranes; (5) characterization of the physics of the taste sensory system stimulated by glutamate from seaweeds using single-molecule receptor taste compound binding assays; and (6) investigations of synergies in taste by computer simulation of the umami receptor.

The plethora of physical studies should be fully integrated to define and characterise the emerging science of gastrophysics with seaweeds as the test case. En route, collaboration with food chemists, phycologists, sensory scientists, science communicators, high-level chefs and gastronomical entrepreneurs will help to shape the research directions and provide the means for implementation of scientific achievements in tomorrow's cuisine.

\section{Conclusion and future outlook}

The empirical world of cooking and gastronomy is a promising new territory for application of state-of-theart methods used in physics and biophysical chemistry that may not only transform our study of this empirical world into a new science, 'gastrophysics', but also revitalize the physics of the kind of soft matter of which foodstuffs are made, potentially leading to new fundamental insights that can be translated into a more scientifically inspired approach to gastronomy. The field of gastrophysics will employ a wide range of the most powerful theoretical, simulational and experimental biophysical techniques to study the structure, dynamics and functional properties of raw and processed foodstuff materials with a focus on small-scale and macromolecular physical properties and how they relate to flavour and texture.

This paper presents a vision of a gastrophysical journey into an overlooked and neglected territory of foodstuff, the seaweeds, well-known in the Asian cuisine but only beginning to enter Western cuisine. Seaweeds are basically unexplored scientifically in relation to gastronomy. For reasons related to the world's future supplies of food, a low-carbon imprint of sustainable food production, human health and nutrition, and gastronomical innovation, seaweeds appear to be an ideal subject of study for the emerging science of gastrophysics.

The future use of seaweeds and seaweed products for human consumption will be a highly innovative enterprise because the market is basically virgin in Europe and North America. There is currently a large import of seaweeds from Asia, and individuals make purchases via the internet, but the potential for seaweed use is increasing steeply because of consumers' growing interest in healthy foods that are produced in an environmentally sustainable way. Many leading chefs and gastronomical entrepreneurs are spearheading this trend, and food writers, nutritionists and food scientists are fuelling the interest with novel ideas and factual information.

Consumers have started asking for products available in restaurants and stores. This underscores an urgent need for scientifically based information on which consumers, producers, and companies can base their purchases and strategies for gastronomical development, respectively.

Hence the time is ripe for gastrophysical studies of seaweeds, and it can be expected that the results of such studies may have an impact on decision-making among producers, manufacturers and gastronomical entrepreneurs. Last but not least, knowledge-based information communicated to the public will provide the best support for consumers' ability to navigate tomorrow's food market, which invariably will involve more seaweed products than we have ever seen before. It is worth pointing out that a recently launched plan in the Nordic countries for a special terroir-based 'New Nordic Diet' does indeed now recommend regular consumption of seaweed products [79].

Application of gastrophysical studies of seaweeds are hence timely and should serve as a nucleus for the growth of a sector comprising the production and processing of seaweeds for human consumption, with a clear aim of creating gastronomical value and, not least, flavour. The anticipated results of gastrophysical investigations of seaweeds will provide a valuable source of knowledge for (1) future recommendations regarding the development and production of select, high-quality seaweeds for human consumption (fresh, dried and processed); (2) best practice designs of drying and storage procedures; (3) selection of algal species with maximal health benefits and desirable sensory perceptions; (4) inspiration of gastronomical entrepreneurs and producers and distributors of seaweed products; and (5) information for the general public about the various benefits of a diet with a certain content of seaweed products.

Wider informed use of seaweeds and seaweed products in the diet is likely to lead to a number of general health benefits and may aid in combating diet-related lifestyle-related diseases. Gastronomical innovation based on seaweeds is expected to create a demand for seaweeds as foodstuff or food ingredients and hence to fuel the creation of new industries and small businesses, as well as to rejuvenate the commercial potential for existing producers of daily foodstuff. The development of farmed seaweed production, possibly with organic certification, will provide a new and sustainable use of the resources of local waters.

\section{Abbreviations}

AA: arachidonic acid; DHA: docosahexaenoic acid; EPA: eicosapentaenoic acid. 


\section{Acknowledgements}

The author gratefully acknowledges many discussions with Per Lyngs Hansen and Amy Rowat about the science and practicalities of cooking and for coining and clarifying the term 'gastrophysics'. Felix Gõni is thanked for references to papers on the science of cooking in the Spanish magazine SEBBM. Mariela Johansen is gratefully acknowledged for careful translation, from Danish into English, of some of the author's writing on seaweeds. MEMPHYS was supported as a centre of excellence by the Danish National Research Foundation for the period 2001 to 2011. The Nordic Food Lab is an independent institution supported by Danish government sources, external funds and private companies, as well as by foundations such as NordeaFonden. This work was supported by a grant (J.nr. 3414-09-02518) from the Danish Food Industry Agency.

\section{Author details}

'MEMPHYS, Center for Biomembrane Physics, Department of Physics, Chemistry and Pharmacy, University of Southern Denmark, Campusvej 55, DK-5230 Odense M, Denmark. ${ }^{2}$ Nordic Food Lab, 93 Strandgade, DK-1401 Copenhagen K, Denmark.

\section{Competing interests}

The author declares that he has no competing interests.

Received: 31 October 2011 Accepted: 4 April 2012

Published: 4 April 2012

\section{References}

1. Brillat-Savarin JA: In Physiologie du goût [The Physiology of Taste: Or, Meditations on Transcendental Gastronomy]. Edited by: Drayton A, transl. London: Penguin Books; 1994:.

2. Kurti N: The physicist in the kitchen. Proc R Inst G B 1969, 42:451-467.

3. This H: In Traité élémentaire de cuisine [Molecular Gastronomy: Exploring the Science of Flavor]. Edited by: DeBevoise MB, transl. New York: Columbia University Press; 2006:

4. This H: In Les secrets de la casserole [Kitchen Mysteries: Revealing the Science of Cooking]. Edited by: Gladding J, transl. New York: Columbia University Press; 2007:

5. Adrià F, Blumenthal H, Keller T, McGee M: Statement on the 'new cookery'. Observer (Lond) 2006, [online article] http://www.guardian.co.uk/ uk/2006/dec/10/foodanddrink.obsfoodmonthly.

6. Barham P, Skibsted LH, Bredie WLP, Bom Frøst M, Møller P, Risbo J, Snitkjær $P$, Mørch Mortensen LM: Molecular gastronomy: a new emerging scientific discipline. Chem Rev 2010, 110:2313-2365.

7. Belitz HD, Grosch W, Schieberle P: In Food Chemistry.. 3 edition. Edited by: Burghagen MM, transl. Heidelberg: Springer; 2004:

8. Fennema's Food Chemistry (Food Science and Technology). In Boca Raton, FL: CRC Press Edited by: Damodaran S, Parkin KL, Fennema OR , 4 2007.

9. Coultate TP: Food: The Chemistry of Its Components. 4 edition. Cambridge, UK: Royal Society of Chemistry; 2002.

10. This H: Hay muy poca ciencia en la industria alimentaria [in Spanish]. SEBBM 2010, 166:25-29.

11. Accum FCA: System of Theoretical and Practical Chemistry Philadelphia: Kimber and Conrad; 1808.

12. Barham P: The Science of Cooking Heidelberg: Springer; 2001.

13. Wolke RL: What Einstein Told His Cook: Kitchen Science Explained New York: W.W. Norton \& Co; 2002.

14. Wolke RL: What Einstein Told His Cook 2: Further Adventures in Kitchen Science-The Sequel New York: W.W. Norton \& Co; 2005.

15. Hillman H: The New Kitchen Science: A Guide to Knowing the Hows and Whys of Fun and Success in the Kitchen New York: Houghton Mifflin; 2003.

16. Joachim D, Schloss A: The Science of Good Food: The Ultimate Reference on How Cooking Works Toronto: Robert Rose; 2008.

17. Potter J: Cooking for Geeks. Real Science, Great Hacks, and Good Food Sebastopol, CA: O'Reilly; 2010

18. Vega C, Ubbibk J, van der Linden E: The Kitchen as Laboratory. Reflections on the Science of Food and Cooking York: Columbia University Press; 2012,

19. McGee H: On Food and Cooking: The Science and Lore of the Kitchen New York: Scribner; 2004, Revised edition.

20. Blumenthal H: The Fat Duck Cookbook London: Bloomsbury; 2008.
21. Clarke C: The Science of Ice Cream Cambridge: Royal Society of Chemistry; 2004.

22. Beckett ST: The Science of Chocolate Cambridge: Royal Society of Chemistry; 2000.

23. Rowat AC, Hollar K, Rosenberg D, Stone HA: The science of chocolate: phase transitions, emulsification, and nucleation. J Chem Educ 2011, 88:29-33.

24. Rowat AC, Hollar K, Rosenberg D, Stone HA: The science of pizza: the molecular origins of cheese, bread, and digestion using interactive activities. J Food Sci Educ 2010, 9:106-112.

25. Mouritsen OG: Sushi: Food for the Eye, the Body, \& the Soul New York: Springer; 2009

26. Myhrvold N, Young C, Bilet M: Modernist Cuisine: The Art and Science of Cooking Bellevue, WA: The Cooking Lab; 2011, 5 vols.

27. Parkers K: Recipe for success: teachers get inspiration from 'gastrophysics'. Phys Educ 2004, 39:19.

28. Ogborn J: Soft matter: food for thought. Phys Educ 2004, 39:45-51.

29. Physics of Biological Systems. Heidelberg: Springer Edited by: Flyvbjerg H, Hertz J, Jensen MH, Mouritsen OG, Sneppen K 1997.

30. Barsanti L, Gualtieri P: Algae: Anatomy, Biochemistry, and Biotechnology Boca Raton, FL: CRC Press; 2006.

31. Andersen RA: Diversity of eukaryotic algae. Biodivers Conserv 1992, 1:267-292.

32. Braune W, Guiry MD: Seaweeds: A Colour Identification Guide to the Common Benthic Green, Brown and Red Algae of the World's Oceans Königstein, Germany: Koeltz Scientific Books; 2011, Revised and translated by Guiry MD.

33. Arasaki S, Arasaki T: Low Calorie, High Nutrition Vegetables from the Sea to Help You Look and Feel Better Tokyo: Japan Publications Inc; 1983.

34. Duarte CM, Marbá N, Holmer M: Rapid domestication of marine species. Science 2001, 316:382-383.

35. Mouritsen OG: Seaweeds. Edible, Available \& Sustainable [in Danish] Copenhagen: Nyt Nordisk Forlag Arnold Busck; 2009.

36. Food and Agriculture Organization of the United Nations: The State of World Fisheries and Aquaculture 2010. [http://www.fao.org/docrep/013/ i1820e/i1820e00.htm].

37. Løvstad Holdt S, Kraan S: Bioactive compounds in seaweed; functional food applications and legislation. J Appl Phycol 2010, 23:543-597.

38. Pereira $L: A$ review of the nutrient composition of selected edible seaweeds. In Seaweed: Ecology, Nutrient Composition and Medicinal Uses. Edited by: Pomin VH. Happauge, NY: Nova Science Publishers; 2012:

39. Colombo ML, Risè $P$, Giavarini $F$, De Angelis $L$, Galli $C$, Bolis $C L$ : Marine macroalgae as sources of polyunsaturated fatty acids. Plant Foods Hum Nutr 2006, 61:67-72

40. Khotimchenko SV, Vaskovsky VE, Titlyanova TV: Fatty acids of marine algae from the Pacific Coast of North California. Botanica Marina 2002, 45:17-22.

41. Dawczynski C, Schubert $R$, Jahreis G: Amino acids, fatty acids, and dietary fibre in edible seaweed products. Food Chem 2006, 103:891-899.

42. Rupérez P: Mineral content of edible marine seaweeds. Food Chem 2002, 79:23-26.

43. Teas J, Pino S, Critchley A, Braverman LE: Variability of iodine content in common commercially available edible seaweeds. Thyroid 2004, 14:836-841.

44. van Netten C, Hoption Cann SA, Morley DR, van Netten JP: Elemental and radioactive analysis of commercially available seaweed. Sci Total Environ 2000, 255:169-175.

45. Sánchez-Machado DI, Lopez-Cervantes J, López-Hernández J, PaseiroLosada P: Fatty acids, total lipid, protein and ash contents of processed edible seaweeds. Food Chem 2004, 85:439-444.

46. MacArtain P, Gill CIR, Brooks M, Campbell R, Rowland IR: Nutritional value of edible seaweeds. Nutr Rev 2007, 65:535-543.

47. Simopoulos AP: The importance of the ratio of $\omega-6 / \omega-3$ essential fatty acids. Biomed Pharmacother 2002, 56:365-379.

48. Valentine RC, Valentine DL: $\Omega-3$ Fatty Acids and the DHA Principle. Boca Raton, FL: CRC Press 2010

49. Poly-unsaturated fatty acids, neural function and mental health. In Biol Skr Dan Vid Selsk Edited by: Mouritsen OG, Crawford MA 2007, 56:1-87.

50. Cunnane SC, Stewart KM: Human Brain Evolution: The Influence of Freshwater and Marine Food Resources Hoboken, NJ: Wiley-Blackwell; 2010.

51. Seaweed Symposium: Seaweeds for Human Consumption, Bioactive Compounds, and Combating of Diseases. An international interdisciplinary 
symposium, Carlsberg Academy, Copenhagen, Denmark; 2010 [http://www. tangbog.dk/?page_id=597].

52. Spirulina in Human Nutrition and Health. Boca Raton, FL: CRC Press Edited by: Gershwin ME, Belay A 2008

53. Ley BM: Chlorella: The Ultimate Green Food Golden Valley, MN: BL Publications/NHL Ministries; 2003.

54. Dillehay T, Ramírez DC, Pino M, Collins MB, Rossen J, Pino-Navarro JD: Monte Verde: Seaweed, food, medicine, and the peopling of South America. Science 2008, 320:784-786.

55. Rhatigan P: Irish Seaweed Kitchen: The Comprehensive Guide to Healthy Everyday Cooking with Seaweeds Co Down, Ireland: Booklink; 2010.

56. Mouritsen OG, Williams L, Bjerregaard R, Duelund L: Seaweeds for umami flavour in the New Nordic Cuisine. Flavour 2012, 1(1):4.

57. Cooper Madlener J: The Seavegetable Book: Foraging and Cooking Seaweed New York: Clarkson N Potter; 1977.

58. Babel K: Seafood Sense: The Truth About Seafood Nutrition \& Safety Laguna Beach, CA: Basic Health Publications; 2005.

59. Bradford P, Bradford M: Cooking with Sea Vegetables: A Collection of Naturally Delicious Dishes Using to the Full the Bountiful Harvest of the Oceans New York: Thorson Publishers; 1985.

60. Chavannes CD: Algues: Légumes de la mer Sète, France: Editions La Plage; 2002.

61. Cooksley VG: Seaweed: Nature's Secret Balancing Your Metabolism, Fighting Disease, and Revitalizing Body \& Soul New York: Stewart, Tabori and Chang; 2007.

62. Ellis L: Seaweed, A Cook's Guide: Tempting Recipes for Seaweed and Sea Vegetables San Francisco: Fisher Books; 1998

63. Fryer L, Simmons D: Food Power from the Sea: The Seaweed Story Austin, TX: Acres U.S.A; 1977.

64. Gusman J: Vegetables from the Sea. Everyday Cooking with Sea Greens New York: William Morrow Cookbooks; 2003.

65. Huston F, Milne X: Seaweed and Eat It: A Family Foraging and Cooking Adventure London: Virgin Books; 2008.

66. Maderia CJ: The New Seaweed Cookbook: A Complete Guide to Discovering the Deep Flavors of the Sea Berkeley, CA: North Atlantic Books; 2007.

67. Lewallen E, Lewallen J: Sea Vegetable Gourmet Cookbook and Wildcrafter's Guide Mendocino, CA: Mendocino Sea Vegetable Co; 1996.

68. Erhart S, Cerier L: Sea Vegetable Celebration Summertown, TN: Tennessee Book Publishing Co; 2001.

69. McConnaughey E: Sea Vegetables: Harvesting Guide \& Cookbook Happy Camp, CA: Naturegraph Publishers; 2002.

70. Harbo RM: The Edible Seashore: Pacific Shores Cookbook \& Guide Surrey, BC: Hancock House; 1988.

71. Druehl L: Pacific Seaweeds: A Guide to Common Seaweeds of the West Coast Madeira Park, BC: Harbour Publishing; 2000.

72. Ninomiya K: Umami: a universal taste. Food Rev Int 2002, 18:23-38.

73. Kasabian A, Kasabian D: The Fifth Taste: Cooking with Umami New York: Universe Publishing; 2005.

74. Blumenthal H, Barbot P, Matsushisa N, Mikuni K: Dashi and Umami: The Heart of Japanese Cuisine London: Eat-Japan, Cross Media; 2009.

75. Mouritsen OG, Styrbæk K: Umami: The Gourmet Ape \& the Fifth Taste [in Danish] Copenhagen: Nyt Nordisk Forlag Arnold Busck; 2011.

76. Zhang F, Klebansky B, Fine RM, Xu H, Pronin A, Liu C, Tachdjian C, Li X: Molecular mechanism for the umami taste synergism. Proc Natl Acad Sci USA 2008, 105:20930-20934.

77. Strauss S: Parse the salt, please. Nat Med 2010, 16:841-843

78. López-López I, Cofrades S, Jiménez-Colmenero F: Low-fat frankfurters enriched with $n-3$ PUFA and edible seaweed: effects of olive oil and chilled storage on physicochemical, sensory and microbial characteristics. Meat Sci 2009, 83:148-154.

79. Mithril C, Dragsted LO, Meyer C, Blauert E, Holt MK, Astrup A: Guidelines for the New Nordic Diet. Pub Health Nutr 2012, 17:1-7.

doi:10.1186/2044-7248-1-6

Cite this article as: Mouritsen: The emerging science of gastrophysics and its application to the algal cuisine. Flavour 2012 1:6.

\section{Submit your next manuscript to BioMed Central and take full advantage of:}

- Convenient online submission

- Thorough peer review

- No space constraints or color figure charges

- Immediate publication on acceptance

- Inclusion in PubMed, CAS, Scopus and Google Scholar

- Research which is freely available for redistribution

Submit your manuscript at www.biomedcentral.com/submit 